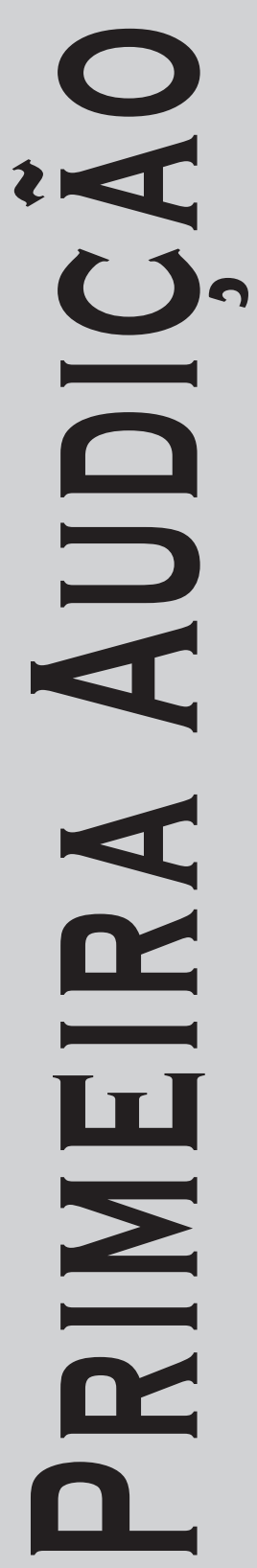

Revista Música Hodie, Goiânia - V.14, 238p., n.1, 2014 


\title{
Anadiplosia para Tirso
}

\author{
Jorge Antunes (Universidade de Brasília, Brasília, DF)
} antunes@unb.br

Esta obra foi composta no LIEM (Laboratorio de Informática y Electrónica Musical) em Madrid, em 2008. O trabalho é inspirado em um poema de Tirso de Molina, o dramaturgo espanhol do século XVI. O poema é um trecho da peça teatral La Gallega MariHernández, e fala da sensualidade, do amor e do ciúme produzido pela atração dos corpos. No meio da obra o compositor usa o pequeno poema na íntegra, na voz de Ana VegaToscano. A terceira estrofe do poema, tem a forma de anadiplose, figura de linguagem em que a última palavra de cada verso é repetida como primeira palavra do verso seguinte. A composição musical também utiliza essa forma. Com esta peça o compositor começou a desenvolver uma linguagem musical que ele chama de "música figural" em que as figuras de linguagem implicam na eloquência que facilita a comunicação musical. O material sonoro básico consiste de uma voz feminina (Anna Vega). Os softwares utilizados foram o GRM-Tools e o Pro Tools.

Jorge Antunes formou-se em violino, composição e regência. Em 1961 se destacou como precursor da música eletrônica no Brasil, ao mesmo tempo em que ingressava no curso de Física da Faculdade Nacional de Filosofia (FNFi). Realizou estudos pós-graduados em composição no Instituto Torcuato Di Tella de Buenos Aires. Estudou no Instituto de Sonologia da Universidade de Utrecht, com uma bolsa do governo holandês, e no Groupe de Recherches Musicales de l'ORTF, onde atuou como compositor-estagiário sob a orientação de Pierre Schaeffer. Fez o Doutorado em Estética Musical na Sorbonne, Universidade de Paris VIII, tendo Daniel Charles como orientador. Ingressou em 1973 no corpo docente da Universidade de Brasília. Foi Professor Titular de Composição Musical na UnB até 2011, quando se aposentou. Continua vinculado àquela Universidade, como Pesquisador Sênior. Obteve vários prêmios nacionais e internacionais. Tem vários CDs, DVDs e livros publicados. É membro da Academia Brasileira de Música e Presidente da Sociedade Brasileira de Música Eletroacústica. Suas obras são publicadas por importantes editoras internacionais: Salabert, Breitpkof\&Hartell, Gerig, Ricordi, Sistrum, Billaudot e Suvini Zerboni.

Jorge Antunes - Formou-se em violino, composição e regência. Realizou estudos pós-graduados em composição no Instituto Torcuato Di Tella de Buenos Aires. Estudou no Instituto de Sonologia da Universidade de Utrecht, com uma bolsa do governo holandês, e no Groupe de Recherches Musicales de l'ORTF, onde atuou como compositor-estagiário sob a orientação de Pierre Schaeffer. Fez o Doutorado em Estética Musical na Sorbonne, Universidade de Paris VIII, tendo Daniel Charles como orientador. Ingressou em 1973 no corpo docente da Universidade de Brasília. Foi Professor Titular de Composição Musical na UnB até 2011, quando se aposentou. Continua vinculado àquela Universidade, como Pesquisador Sênior. Obteve vários prêmios nacionais e internacionais. Tem vários CDs, DVDs e livros publica- dos. É membro da Academia Brasileira de Música e Presidente da Sociedade Brasileira de Música Eletroacústica. Suas obras são publicadas por importantes editoras internacionais: Salabert, Breitpkof\&Hartell, Gerig, Ricordi, Sistrum, Billaudot e Suvini Zerboni. 